Author accepted version: accepted for publication in the European Journal of Special Needs Education, $10^{\text {th }}$ June 2020

\title{
What makes a good teacher? Comparing the perspectives of students on the autism spectrum and staff
}

Harriet Hummerstone ${ }^{\mathrm{a} *}$ and Sarah Parsons ${ }^{\mathrm{b}}$

${ }^{a}$ Centre for Research in Inclusion, Southampton Education School, University of Southampton, Southampton, UK; ${ }^{b}$ Centre for Research in Inclusion, Southampton Education School, University of Southampton, Southampton, UK

Harriet Hummerstone

ORCID ID: 0000-0002-4134-4569

Twitter: @hhummerstone

LinkedIn: linkedin.com/in/hhummerstone

Telephone: 07525070441

Email: hhummerstone@hotmail.com

Sarah Parsons

ORCID ID: 0000-0002-0815-5272

Telephone: 02380592977

Email:s.j.parsons@soton.ac.uk 


\title{
What makes a good teacher? Comparing the perspectives of students on the autism spectrum and staff
}

\author{
Involving students on the autism spectrum in decision-making about their \\ education is good practice for inclusion and mandated by the Special Educational \\ Needs and Disability Code of Practice in England. This article reports on two \\ linked studies investigating the perspectives of 12 secondary mainstream students \\ on the autism spectrum aged 11-15 years, and their teachers $(n=10)$, about \\ teaching and support. Students and teachers agreed that staff members were more \\ likely to focus on the needs of the class rather than the needs of the individual \\ student, which could be very difficult to navigate successfully. In addition, \\ students emphasised the importance of feeling understood and supported in \\ school. However, differences in sensory perceptions and communication meant \\ that students sometimes felt misunderstood by staff, leading to feelings of hurt \\ and frustration. This suggests it is important to understand the needs of individual \\ students on the autism spectrum, and adapt teaching and pastoral strategies \\ accordingly, in order to promote an appropriately inclusive educational \\ environment.
}

Keywords: autism, education, photo elicitation, activity-centred interviews secondary, teachers, mainstream, school

\section{Introduction}

It is well established that children and young people are concerned with having a say in the decisions that affect them (e.g. Kilkelly et al., 2005; Lundy, 2007), and Article 12 of the United Nations Convention on the Rights of the Child (UNCRC, 1989) has had a significant impact on social and educational policies nationally and internationally (Lundy, 2012). However, concerns from adults about children's capabilities to form a mature and informed view exist internationally (Reynaert, Bouverne-De Bie \& Vandevelde, 2009); and for pupils on the autism spectrum, there are additional assumptions that their views are difficult to access due, at least in part, to the social and 
communication difficulties that characterise an autism spectrum diagnosis (Greathead et al., 2016). Consequently, there is still a long way to go before children’s voices, especially those on the autism spectrum ${ }^{1}$, are adequately represented in formal processes, including educational planning, both internationally (Gillespie-Lynch et al., 2017; Chandroo et al., 2018) and in the UK (Gaona et al., 2019; Palikara et al., 2018).

In England, the latest revision of the Special Educational Needs and Disability Code of Practice (hereafter referred to as the SEND CoP, DoE \& DoH, 2015) has a strengthened emphasis - relative to the previous version (DfES, 2001) - on the involvement and consultation of young people with SEND, mandating that young people’s views must be sought regarding decisions that affect their education:

Local authorities must not use the views of parents as a proxy for young people's views. Young people will have their own perspective and local authorities should have arrangements in place to engage with them directly. (p. 22; emphasis in original)

Consequently, the views of children and young people who fall within the SEND CoP remit are given considerable primacy in shaping their educational provision, at least in policy terms. This marginalisation is especially concerning given the numbers of children involved, with autism identified as the primary need of the largest group (almost a third) of students with an Education, Health and Care Plan (EHCP), which provides higher levels of support for more complex needs (DfE, 2019a). The majority (c.70\%) of pupils on the autism spectrum attend mainstream schools, with 42,500 in

\footnotetext{
${ }^{1}$ The phrase 'on the autism spectrum' is used throughout this paper to reflect the view that '...beyond the autism diagnosis - and its negative as well as positive associations - there is a unique person whose human rights should be respected.' (Vivanti, 2020, p.692)
} 
secondary mainstream education in England (DfE, 2019b). Therefore, there are significant numbers of students who should have their voices heard regarding educational decisions and planning, but about whose experiences we know very little.

The marginalisation of autistic voices has also been recognised more widely, with many researchers and advocates calling for more direct involvement of autistic people in research (Milton, Mills \& Pellicano, 2014; Parsons et al., 2011; 2020). Older children and adolescents are especially underrepresented in the autism research literature (Pellicano, Dinsmore \& Charman, 2014; Parsons et al., 2011) with their experiences generally considered under-researched (Holt, 2010). Elliot-Johns et al. (2012) and Saggers (2015) suggest that a greater understanding of the views of students on the autism spectrum is needed 'to help inform positive educational experiences and learning outcomes’' (Saggers, 2015, p.2).

In this context, there is an emerging body of research exploring the views of students on the autism spectrum that adds greater insight into their educational experiences. Students on the autism spectrum report different preferences regarding social relationships and friendships compared to their neurotypical peers, which can lead to social issues such as isolation and bullying if not successfully navigated (Jones, Huws \& Beck, 2013). Students have also identified their strengths and challenges (e.g. Van Hees, Moyson \& Roeyers, 2015), including sensory experiences of school and classroom environments that may feel overwhelming (Ellis, 2017; Healy, Msetfi \& Gallagher, 2013; Humphrey \& Lewis, 2008a). A key message is that the individual differences between students on the autism spectrum cannot be underestimated or assumed when it comes to their school experiences (Moyse \& Porter, 2015; Goodall \& Mackenzie, 2019). Students must not be conceptualised as a homogeneous group simply based on a label of 'autism', which is why finding out more about their views is so vital. 
What the literature tells us much less about is how students on the spectrum think about teachers and teaching, and the teaching strategies they feel are more or less helpful for them. The SEND CoP (DfE, 2015) says teachers need to know 'how to adapt teaching and learning to meet a particular type of SEN' (p.69). Jordan (2005) concurs, observing that 'Children with ASDs (sic) often (but not always) require different approaches [to teaching] rather than just more (or more focused) of the same' (p.117). Consequently, input from the students themselves is crucial in assessing whether their needs can be met with general inclusive teaching strategies, autism-specific strategies, or a combination of both to achieve their full potential. Students' insights may therefore be able to help teachers promote more inclusive school contexts.

\section{The contribution of this research}

This research was carried out between December 2013 - January 2014 (Study 1), and December 2015 - May 2016 (Study 2) with students on the autism spectrum and their teachers in secondary schools in England. Both studies were conducted as part of educational qualifications; the first study acted as a methodological pilot, but the strength of the findings merited inclusion in this paper. Both studies sought to answer the following questions:

(1) What do pupils on the autism spectrum think about the teaching they experience at school and how their experiences as learners might be improved?

(2) What do staff members think about how the experiences of students on the autism spectrum as learners might be improved? 


\section{Methodology}

Both studies adopted a qualitative and participatory approach to explore student and teacher views using photo-elicitation (with students) and semi-structured interviews (with both students and teachers).

\section{Participants}

Participants were purposively sampled from secondary mainstream schools in the South of England via the school’s Special Educational Needs Co-ordinator (SENCo). All students came from a White British background and had been identified and assessed as being on the autism spectrum by educational psychologists, apart from $\mathrm{Hanzo}^{2}$, who was still going through the diagnostic process during fieldwork (see Table 1 for further details).

[Table 1 to be inserted here]

In addition, for Study 1, three teachers (2 males, 1 female) who taught the students were recommended by the SENCO as practitioners who consistently demonstrated inclusive practice. For Study 2, seven staff members (two males, five females) from two schools who taught at least one of the student participants volunteered to take part (see Table 2 for further details).

[Table 2 to be inserted here]

\footnotetext{
${ }^{2}$ The students selected their own pseudonyms and their responses have been reported using gender neutral pronouns to limit the chances of identification. The staff members expressed no preference, and therefore their pseudonyms were chosen at random.
} 


\section{Methods}

Photo-elicitation (student participants)

Photo-elicitation is defined in these studies as using photos taken in school by the student participants to facilitate a discussion via semi-structured interview. This visual method was chosen as it is useful for engaging children, exploring their tacit knowledge, and prompting additional reflection to provide richer details (Shaw, 2020). Visual cues can also provide a helpful structure to the interview process (Lewis, Newton \& Vials, 2008) and prompt both verbal and non-verbal communication, allowing a focus on the students' capability of communication rather than limitations (Aldridge, 2007).

Semi-structured interviews (all participants)

Semi-structured interviews were chosen as they offered the best compromise for encouraging discussion and gathering rich data (Bellotti, 2014). They also give the option for clarification, exploration and freedom of answers that would arguably not have been possible to achieve in a more structured interview (Kellett, 2011).

\section{Procedure}

\section{Students}

In both studies, students and their parents were given study information sheets and had a chance to discuss them before signing consent forms (parents) or assent forms (students). The students then met individually with a researcher and walked around the school during lesson time (accompanied by a researcher) taking photographs representing either things they liked/disliked (Study 1) or curriculum subjects (Study 2). Photographs were taken using a digital camera as this provided an immediate image of 
the photograph taken, meaning students could re-take photographs if desired, e.g. they were poor quality. These photographs were then printed off and used subsequently to facilitate the semi-structured interviews, which took place a few days later in the learning support areas of each school. Students met individually with the researcher who gave them hard copies of the photographs taken. They were reminded of their right to stop the interview at any point and given an opportunity to familiarise themselves with the controls of the researcher's video camera and tripod, so that they could stop or start the recording at any time without explanation. Student interviews were videoed so that their discussion of, and gestures towards, the photographs, and other non-verbal communication during the interview could be easily recorded. Once students were confident with operating the camera, they labelled and numbered the photographs with a few words to summarise what the photo represented (as this was not always clear). They were then asked to arrange the photographs in responses to questions asked by the researcher (see Table 3) to help them structure their answers.

[Table 3 to be inserted here]

This task was based on Thomas and O’Kane’s (1999) diamond-ranking method, where nine photographs are ranked in a diamond shape to demonstrate 'most' to 'least' responses to a question (e.g. most / least liked). Although students often took more than nine photographs, their sorting arrangements still allowed them to rank images relative to each other. Once the questions were asked, students were thanked for their time and asked if they had any final thoughts or questions. Once any further discussion was complete, they turned off the video camera. Most interviews lasted around 45-50 minutes. 


\section{Staff}

Staff interviews were conducted in a small private meeting room at each of the schools. Upon arrival, teachers were greeted by the researcher and given the opportunity to reread the study information sheet (previously sent via email) and ask any questions before signing consent forms. Teachers were reminded that they did not have to answer all the questions if they felt uncomfortable, that they could stop the interview at any point, and that answers were confidential. Once they were ready to begin, they were asked how long they had been teaching, before being asked the questions in Table 4 .

[Table 4 to be inserted here]

Interviews were recorded on a password-protected audio-recorder. Once the questions had been asked, teachers were invited to give any final comments or ask questions before being thanked for their time and concluding the interview. Interviews lasted for around 20-30 minutes.

\section{Analysis}

Transcripts of student and staff interviews were analysed using thematic analysis, as it allows for a ‘bottom up’ approach to the research, as well as identifying key themes (Crawford, Brown \& Majomi, 2008). The key themes from each study were identified and compared, and transcripts were re-visited for further clarification and detail where necessary. This allowed the findings to be organised into higher-level concepts that were evident across both studies.

\section{Ethical considerations}

Ethical approval was sought and granted from the Faculty of Social, Human and Mathematical Sciences Research Ethics Committee at the University of Southampton 
[Study 1: 5626, Study 2: 17434]. Approval to conduct the research was initially sought from the head teachers and SENCOs of the schools. Consent was gained from staff and students’ parents by sending information sheets via email and being given opportunities to ask questions in advance of signing consent forms. Students received an adapted information sheet and assent form because of their age, as recommended by Brewster and Coleyshaw (2010), which they also signed after being given the opportunity to ask questions. However, an approach of 'ongoing assent' was also adopted when working with them, which Cocks (2006) argues is a better indication of agreement to participation than informed consent when working with children.

\section{Findings}

\section{The needs of the individual vs. the needs of the group}

There was a clear difference in the priorities of the students and the staff when it came to teaching students on the autism spectrum, despite all the staff mentioning how important it was to consider individual students when trying to support them. Common examples given included planning lessons around the strengths and weaknesses of the entire class (which was identified as good practice by 6/10 teachers) and thinking about how an individual student could impact their peers during classwork:

...whenever there is some sort of paired work or group work - it is essential to think about those social relationships that Bob has and bear that in mind [when arranging groups] (Steve, Classroom teacher, Study 2)

The focus on the whole class rather than individual students was also commented on by 6/12 students, with some students expressing that they needed more support than was initially given to the whole class: 
Because it's less the individual in mainstream. In schools I think, it's more 'teach a group’ rather than 'teach the individual'. (Jeffrey, Student, Study 1)

You [the teacher] give me a little help and then it feels like it helps me complete that one question, and then I've still got a load of other questions to do. And then I get stuck within, like, the next two questions, and so on... (Sage, Student, Study 2)

There appears to be a tension between the needs of the students on the autism spectrum within a classroom, and the needs of all the other students, and both student and staff discussions revealed that this could be tricky to navigate. Some staff $(4 / 10)$ noted that they did not change their whole-class teaching practices if their classes included students on the autism spectrum, and just offered additional explanations if required:

With the best will in the world, I know we all talk about 'personalised teaching', but you can't plan for the whole class around one person (Leah, Head of Department, Study 1)

[In Sage's class] there are so many kids who will just get on with doing what they need to do, that actually, I CAN then say 'now I'm going to talk to Sage' to see if [they] understand what we're doing (Megan, Classroom teacher, Study 2)

Other whole-class practices also significantly affected students on the autistic spectrum; for example, when a teacher shouted, the negative impact of this was mentioned by most of the students (10/12), even if they were not the recipient of the shouting:

[The teacher] is always shouting and stuff. It makes you [clenches fists and hunches over, teeth gritted]...I'm always on edge (Daz, Student, Study 1)

Cos... when we're in [lesson], most of the teachers just shout at me, and I don't like it...And I just get...upset (Genji, Student, Study 2) 


\section{The importance of being understood to feel supported}

All twelve students mentioned the importance of staff who were caring and supportive, giving positive examples where they had felt supported:

[describing what makes a good teacher] Hmm...well, first you need a cauldron, you need to put some, a dash of niceness...two spoons of sweetness...a bag, a bag of umm, a bag of fun-ness....and then you mix it with a spoon, with a spoon of direction. And then you put it in the oven of, err, good listening skills, and then you put the icing, the icing of, umm, of incredibly awesomeness on top and a dash of sprinkles of umm...of more niceness! (Benton, Student, Study 1)

Students also described negative examples of when they felt they had been unsupported, and at worst, made to feel bad by members of staff:

I'll be in [the lesson] and I'll accidentally [do something wrong]...[imitates staff member shrieking] “No, no, no, that’s not right!” And I’m like, “Jesus, woman, it’s my first time!” (Yazi, Student, Study 2)

I've got this anxiety thing as well where I bite stuff, and I was biting the lid off my pen [mimes], and [the teacher]...shouted at me saying ‘why are you biting?’ and I said 'because I've got anxiety issues' and [the teacher] said 'that is the most stupid excuse I’ve ever heard of!' ... and I was like, 'I wasn’t even doing anyone any harm!' (Daz, Student, Study 1)

Despite the value of emotional support from teachers that the students expressed, staff did not give any concrete examples from the classroom of where they had offered emotional support to students (excluding additional pastoral roles, such as being a Head of Year). It was clear that staff felt that the most effective support they could offer to the students was academic support within the classroom (see Table 5). However, students valued conversations where teaching staff ‘checked in' with them and asked how they were getting on generally. 
[Table 5 to be inserted here]

Closely linked to the feeling of being supported by staff was students commenting on the importance of 'being understood' by teachers:

[describing a favourite teacher] He gives me chances, he understands me, and we - I don't know if it's because we both like the same subject or something, I don't know...[if all my teachers could be like him] that would be the best thing in the world... (Hanzo, Student, Study 2)

All staff members also mentioned that understanding students was a good way to support them:

You wanna work with what they've [students on the autistic spectrum] got...you've kinda got to know them and their little foibles, and then you've got to work with the foibles! (Amy, Head of Department, Study 2)

However, an area of understanding not mentioned by staff was the impact of sensory differences students on the autism spectrum experience. By contrast, all the students were able to identify an area of sensory difference that either improved the quality of their classroom experience if met or decreased the quality if unmet (see Table 6).

[Table 6 to be inserted here]

\section{Discussion}

This study illuminates how effective photo-elicitation can be for exploring the views of mainstream secondary students on the autism spectrum about school, teachers, and their experiences of learning. It is a straightforward, yet powerful, tool that could be used within schools to enable students to contribute their views within the context of the SEND CoP in England, and within research and practice on children's voices 
internationally. While many of the findings chime with existing literature, this study adds additional empirical support to the importance of understanding the perspectives of students on the autism spectrum, not least because of the ways in which they may differ from their teachers. The findings also demonstrate that even though there is a sizeable literature detailing how best to support students on the autism spectrum, there remains patchy implementation of such strategies.

Despite being conducted in different schools, there was agreement across the two studies about what students on the autism spectrum wanted from their teachers and what their teachers thought was best practice in terms of support. Many of the students reported that they were not understood by most teachers, despite the same teachers having in-depth knowledge of personalised academic strategies that were used to support their learning in the classroom. Additionally, both students and staff agreed that a lack of information equated to a lack of understanding, and therefore less effective support. These differences seem to stem from the type of support that staff were providing compared to the type of support students valued. For example, Fouse (1999) comments that providing emotional support could be difficult for some educational practitioners who see their role as 'strictly academic' (p.198). Indeed, teachers reported a lack of specialised support and understanding (including their own), which meant they often felt they were not providing the best support to students on the autism spectrum: yet were unable to see a way to change this. This corresponds to findings that illustrate teachers' perceived lack of confidence in teaching students on the autism spectrum (e.g. the All Party Parliamentary Group on Autism [APPGA], 2017). Lewis and Norwich (2005) describe the "general differences" (p.3) position to education, which identifies students as having three levels of pedagogic need that must be met by their education: 
needs that are common to all students, needs that are specific to a particular group of students, and needs that are specific to the individual student. This seems to fit with the staff members' perceptions that autism-specific training could help them to better support the students in schools. By contrast, the students appear to have adopted a "unique differences" (ibid) position, focusing primarily on the needs that are common to all students and those that are specific to the individual. Consequently, these students valued staff having knowledge about their individual differences rather than about autism generally.

There were also clear differences between the students’ and staff perspectives regarding the 'best' way to support students on the autism spectrum in secondary mainstream schools. The most obvious of these was the tension between meeting the needs of the group (prioritised by staff) and meeting the needs of the individual (prioritised by students). This echoes Lalvani’s (2013) findings that teachers' beliefs about special education are often related to the medical model of disability, i.e. the idea that students with additional needs should to be able to 'keep pace' with their typically developing peers and adapt accordingly. Similarly, Lynch and Irvine (2009) suggest that as children on the autism spectrum grow older, education becomes more standardised. Consequently, teachers are more likely to promote 'mainstreaming' where students are expected to interact within the structure of the classroom, as opposed to taking a more inclusive approach where the classroom environment is adapted to meet the needs of the student. Additionally, Hobson (2002) suggests that individuals on the autism spectrum must be challenged to interact with the social world around them in order to develop their understanding of other people's perspectives. This view was reflected in the staff comments that suggested students must adhere to the social group within the classroom. 
However, Ravet (2011) cautions about mainstreaming strategies, suggesting part of the problem is that teachers may not realise that students on the autism spectrum have 'a unique and distinct way of thinking, communicating and interacting' (p.676) which require teachers to adjust teaching strategies accordingly. Similarly, the misunderstandings mentioned by the students demonstrate what Milton (2012) describes as the 'double-empathy problem'; the mutual misunderstanding that occurs when two members of different groups (in this context, students on the autism spectrum and neurotypical teachers) try to communicate. This is in line with the students' comments about wanting staff members to understand their individuals needs more than staff currently demonstrate.

Students were clear about where and how teachers' strategies could be adjusted to make them feel more included. Crucially, students felt that 'being understood' was the most important feature of excellent support and teaching, as also reported by the APPGA (2017). This included adapting communication styles, allowing discussions of personal interests and using these to engage with the lesson content, and recognising when the students were becoming frustrated and stressed to help them re-focus. Knowing about individual interests was identified by students as an important indicator of 'being understood' by teachers. This is a strategy well-documented in the educational literature (e.g. Zilli, Parsons \& Kovshoff, 2019; Cowan \& Allen, 2007; Leach \& Duffy, 2009), and identified as good practice for autism education (Charman et al., 2011; National Autistic Society, 2018; Martin \& Milton, 2018). It is interesting that despite these consistent recommendations for good teaching practice, students reported that they did not feel this interest or understanding from teachers. This could suggest that these practices are still not being consistently implemented, and therefore student 
reports remain an important source of evidence about whether and how good practice is happening in the classroom.

Another vital area of 'being understood' was recognising how sensory differences impact, often profoundly, on classroom experiences. This was something discussed by all the students and none of the teachers, suggesting there is an important gap in awareness that needs to be addressed. There are many supporting examples from the research literature; for example, the noise and chaotic environment of school (and the usefulness of an accompanying 'safe space' to retreat to) have also been mentioned by others (e.g. Goodall \& Mackenzie, 2019; Williams \& Hanke, 2007). Again, despite sensory difficulties being a well-reported issue for many young people on the autism spectrum, there appears to be a lack of awareness and consideration of how sensory needs can be more effectively addressed in practice by teachers (at least within these two schools).

In conclusion, students on the autism spectrum wanted their teachers to have a good understanding of them as individual students - their personal interests, their background and their sensory differences - in order to support them effectively in the classroom. Knowledge of autism is important, but lack thereof should not be considered a barrier to implementing many of the strategies identified here. The key message for teachers is to focus on building their confidence and knowledge of individual students on the autism spectrum, through nurturing good relationships and finding out what the student is interested in, in order to develop teaching strategies that can be inclusive of a range of needs. 
Acknowledgements

With many thanks to the students and staff who participated in the studies, and for both schools and additional staff who enabled this to happen. Thanks also to Professor Kyriaki Messiou for her support and guidance throughout this research.

Declaration of interest statement

All authors declare no conflict of interests. 


\section{References}

Aldridge, J. (2007). Picture this: the use of participatory photographic research methods with people with learning disabilities. Disability \& Society, 22 (1), 1-17.

All Party Parliamentary Group on Autism (2017). Autism and education in England 2017 [online]. Available from: https://www.autism.org.uk/ /media/nas/getinvolved/campaign/appga/appga-autism-and-education-report.ashx?la=en-gb [Accessed 23.03.2020]

Bellotti, E. (2014). Qualitative Networks: Mixed Methods in Sociological Research. Oxon: Routledge.

Brewster, S. and Coleyshaw, L. (2010). Participation or exclusion? Perspectives of pupils with autism spectrum disorders on their participation in leisure activities. British Journal of Learning Disabilities, 39, 284-291.

Chandroo, R., Strnadová, I., and Cumming, T. M. (2018). A systematic review of the involvement of students with autism spectrum disorder in the transition planning process: Need for voice and empowerment. Research in Developmental Disabilities, 83, 8-17.

Charman, T., Pellicano, L., Peacey, L., Peacey, N., Forward, K. and Dockrell, J. (2011). What is good practice in autism education? Autism Education Trust [online]. Available from: https://network.autism.org.uk/sites/default/files/ckfinder/files/AET\%20Good\%2 0Practice\%20in\%20Autism\%20Education.pdf [Accessed 06.01.2020]

Cocks, A.J. (2006). The ethical maze: finding an inclusive path towards gaining children’s agreement to research participation. Childhood, 13 (2), 247-266.

Cowan, R.J. and Allen, K. (2007). Using naturalistic procedures to enhance learning in individuals with autism: a focus on generalized teaching within the school setting. Psychology in Schools, 44 (7), 701-715.

Crawford, P., Brown. B. and Majomi, P. (2008). Professional identity in community mental health nursing: a thematic analysis. International Journal of Nursing Studies, 45 (7), 1055-1063.

Department for Education and Skills (2001). Special Education Needs: Code of Practice [online]. Available from: http://webarchive.nationalarchives.gov.uk/20130403141846/https://www.educat 
ion.gov.uk/publications/standard/publicationDetail/Page1/DfES\%200581\%2020

$\underline{01}$ [Accessed 01.12.2019]

Department for Education (2015). Special educational needs and disability code of practice: 0 to 25 years. [online]. Available from:

https://assets.publishing.service.gov.uk/government/uploads/system/uploads/atta chment_data/file/398815/SEND_Code_of_Practice_January_2015.pdf

[Accessed 23.02.2020]

Department for Education (2019a). Special educational needs in England: January 2019 Additional tables [online]. Available from:

https://assets.publishing.service.gov.uk/government/uploads/system/uploads/atta chment_data/file/814247/SEN_2019_Additional_tables.xlsx [Accessed 02.12.2019]

Department for Education (2019b). Special educational needs in England: January 2019 National tables [online]. Available from:

https://assets.publishing.service.gov.uk/government/uploads/system/uploads/atta chment_data/file/814245/SEN_2019_National_tables.xlsx [Accessed 02.12.2019]

Elliot-Johns, S., Booth, D., Rowsell, J., Puig, E. and Paterson, J. (2012). Using student voices to guide instruction. Voices from the Middle, 19 (3), 25-31.

Ellis, J. (2017). Researching the social worlds of autistic children: an exploration of how an understanding of autistic children's social worlds is best achieved. Children \& Society, 31 (1), 23-36.

Fouse, B. (1999). Creating a "Win-Win” IEP for Students with Autism: A How-To Manual for Parents and Educators ( $2^{\text {nd }}$ Edn.). Texas: Future Horizons.

Gaona, C., Castro, S., and Palikara, O. (2019). The views and aspirations of young people with autism spectrum disorders and their provision in the new Education Health and Care plans in England. Disability and Rehabilitation, 1-12.

Gillespie-Lynch, K., Bublitz, D., Donachie, A., Wong, V., Brooks, P. J., and D’Onofrio, J. (2017). "For a long time our voices have been hushed": Using student perspectives to develop supports for neurodiverse college students. Frontiers in Psychology, 8, 544. 
Goodall, C. and Mackenzie, A. (2019). What about my voice? Autistic young girls’ experiences of mainstream school. European Journal of Special Needs Education, 34 (4), 499-513.

Greathead, S., Yates, R., Hill, V., Kenny, L., Croydon, A., and Pellicano, E. (2016). Supporting children with severe-to-profound learning difficulties and complex communication needs to make their views known. Topics in Language Disorders, 36 (3), 217-244.

Healy, S., Msetfi, R. and Gallagher, S. (2013). 'Happy and a bit nervous’: the experiences of children with autism in physical education. British Journal of Learning Disabilities, 41 (3), 222-228.

Hobson, P. (2002). The Cradle of Thought: Exploring the Origins of Thinking. London: Macmillan.

Holt, L. (2010). Young people’s embodied social capital and performing disability. Children's Geographies, 8, 25-37.

Humphrey, N. and Lewis, S. (2008a). 'Make me normal': the views and experiences of pupils on the autistic spectrum in mainstream secondary schools. Autism, 12 (1), 23-46.

Jones, R.S.P., Huws, J.C. and Beck, G. (2013). 'I'm not the only person out there': insider and outsider understandings of autism. International Journal of Developmental Disabilities, 59 (2), 134-144.

Jordan, R. (2005). Autism spectrum disorders. In: A. Lewis and B. Norwich (Eds.) Special teaching for special children? Pedagogies for inclusion. Maidenhead, UK: Open University Press.

Kellett, M. (2011). Researching with and for children and young people. Centre for Children and Young People: Background Briefing Series [online] Available from:

http://epubs.scu.edu.au/cgi/viewcontent.cgi?article=1044\&context=ccyp_pubs [Accessed 07.05.2020]

Kilkelly, U., Kilpatrick, R., Lundy, L., Moore, L., Scraton, P., Davey, C., Dwyer, C., and McAlister, S. (2005) Children's rights in Northern Ireland [online]. Available from: http://dera.ioe.ac.uk/9165/1/22323\%20Final.pdf [Accessed 02.03.2020] 
Lalvani, P. (2013). Privilege, compromise or social justice: teachers' conceptualisations of inclusive education. Disability \& Society, 28 (1), 14-27.

Leach, D. and Duffy, M.L. (2009). Supporting students with autism spectrum disorders in inclusive classrooms. Intervention in School and Clinic, 45 (1), 31-37.

Lewis, A., Newton, H., and Vials, S. (2008). Realising child voice: the development of Cue Cards. Support for Learning, 23 (1), 26-31.

Lundy, L. (2007). 'Voice' is not enough: conceptualising Article 12 of the United Nations Convention on the Rights of the Child. British Educational Research Journal, 33 (6), 927- 942.

Lundy, L. (2012). Children's rights and educational policy in Europe: The implementation of the United Nations Convention on the Rights of the Child. Oxford Review of Education, 38 (4), 393-411.

Lynch, S.L. and Irvine, A.N. (2009). Inclusive education and best practice for children with autism spectrum disorder: an integrated approach. International Journal of Inclusive Education, 13 (8), 845-859.

Martin, N. and Milton, D. (2018). Supporting inclusion of autistic children. In: G. Knowles (Ed.). Supporting Inclusive Practice and Ensuring Opportunity is Equal for All ( $3^{\text {rd }}$ Edn). Oxon: Routledge.

Milton, D. E. (2012). On the ontological status of autism: the 'double empathy problem’. Disability \& Society, 27 (6), 883-887.

Milton, D., Mills, R., and Pellicano, E. (2014). Ethics and autism: where is the autistic voice? Commentary on Post et al. Journal of Autism and Developmental Disorders, 44 (10), 2650-2651.

Moyse, R. and Porter, J. (2015). The experience of the hidden curriculum for autistic girls at mainstream primary schools. European Journal of Special Needs Education, 30 (2), 187-201.

National Autistic Society (2018). In the classroom [online]. Available from: http://www.autism.org.uk/professionals/teachers/classroom.aspx [Accessed 24.01.2020]

Palikara, O., Castro, S., Gaona, C., and Eirinaki, V. (2018). Capturing the voices of children in the Education Health and Care plans: are we there yet? Frontiers in Education, 3 (24), 1-9. 
Parsons, S., Guldberg, K., MacLeod, A., Jones, G., Prunty, A. and Balfe, T. (2011). International review of the evidence on best practice in educational provision. European Journal of Special Needs Education, 26 (1), 47-63.

Parsons, S., Yuill, N., Good, J., \& Brosnan, M. (2020). 'Whose agenda? Who knows best? Whose voice?' Co-creating a technology research roadmap with autism stakeholders. Disability \& Society, 35 (2), 201-234.

Pellicano, E., Dinsmore, A. and Charman, T. (2014). What should autism research focus upon? Community views and priorities from the United Kingdom. Autism, 18 (7), 756-770.

Ravet, J. (2011). Inclusive/exclusive? Contradictory perspectives on autism and inclusion: the case for an integrative position. International Journal of Inclusive Education, 15 (6), 667- 682.

Reynaert, D., Bouverne-De Bie, M. and Vandevelde, S. (2009). A review of children’s rights literature since the adoption of the United Nations Convention on the Rights of the Child. Childhood, 16 (4), 518-534.

Saggers, B. (2015). Student perceptions: improving the educational experiences of high school students on the autism spectrum. Improving Schools, 18 (1), 35-45.

Shaw, P.A. (2020). Photo-elicitation and photo-voice: using visual methodological tools to engage with younger children's voices about inclusion in education. International Journal of Research \& Method in Education [online]. Available from: https://doi.org/10.1080/1743727X.2020.1755248 [Accessed 01.06.2020]

Thomas, N. and O’Kane, C. (1999). Children’s participation in reviews and planning meetings when they are 'looked after' in middle childhood. Child \& Family Social Work, 4, 221-230.

United Nations Convention on the Rights of the Child [UNCRC] (1989). Article 12. [online]. Available from: https://downloads.unicef.org.uk/wpcontent/uploads/2016/08/unicef-convention-rights-childuncrc.pdf?.ga=2.49756582.1650560467.1584979599-414396307.1584979599 [Accessed 20.01.2020]

Van Hees, V., Moyson, T. and Roeyers, H. (2015). Higher education experiences of students with autism spectrum disorder: challenges, benefits and support needs. Journal of Autism and Developmental Disorders, 45 (6), 1673-1688. 
Williams, J. and Hanke, D. (2007). 'Do you know what sort of school I want?': optimum features of school provision for pupils with autistic spectrum disorder. Good Autism Practice (GAP), 8 (2), 51-63.

Vivanti, G. (2020). Ask the Editor: What is the most appropriate way to talk about individuals with a diagnosis of autism? Journal of Autism and Developmental Disorders, 50, 691-693.

Zilli, C., Parsons, S. and Kovshoff, H. (2019). Keys to engagement: a case study exploring the participation of autistic pupils in educational decision-making at school. British Journal of Educational Psychology [online]. Available from: https://doi.org/10.1111/bjep.12331 [Accessed 02.03.2020] 
Table 1. Student participant details

\begin{tabular}{|c|c|c|c|c|}
\hline Pseudonym & Study & Age & School Year & Diagnosis received \\
\hline Benton & 1 & 11 & 7 & Autism Spectrum Disorder \\
\hline Daz & 1 & 12 & 8 & Asperger Syndrome \\
\hline Jeffrey & 1 & 15 & 10 & Asperger Syndrome \\
\hline Lewis & 1 & 13 & 9 & Autism Spectrum Disorder \\
\hline Matthew & 1 & 15 & 10 & Autism Spectrum Disorder \\
\hline Stanley & 1 & 12 & 7 & Asperger Syndrome \\
\hline Yazi & 2 & 11 & 7 & Asperger Syndrome \\
\hline Sage & 2 & 12 & 8 & Autism Spectrum Disorder \\
\hline Genji & 2 & 11 & 7 & Autism Spectrum Disorder \\
\hline Hanzo & 2 & 12 & 8 & Undergoing diagnostic process \\
\hline Bob & 2 & 12 & 8 & Autism Spectrum Condition \\
\hline Jack & 2 & 11 & 7 & Asperger Syndrome/ADHD \\
\hline
\end{tabular}


Table 2. Staff participant details

\begin{tabular}{|c|c|c|c|c|c|}
\hline Pseudonym & Study & Age & Sex & Occupation & Experience \\
\hline Harry & 1 & $40-50$ & $\mathrm{M}$ & Head of Department & 18 years \\
\hline Leah & 1 & $40-50$ & $\mathrm{~F}$ & Head of Department & 17 years \\
\hline Wayne & 1 & $30-40$ & $\mathrm{M}$ & Classroom teacher/Head of Year & 11 years \\
\hline Dave & 2 & $30-40$ & $\mathrm{M}$ & Classroom teacher & 4 years \\
\hline Amy & 2 & $40-50$ & $\mathrm{~F}$ & Head of Department & 17 years \\
\hline Sarah & 2 & $50-60$ & $\mathrm{~F}$ & Classroom teacher & $30+$ years \\
\hline Megan & 2 & $30-40$ & $\mathrm{~F}$ & Classroom teacher & 6 years \\
\hline Nancy & 2 & $30-40$ & $\mathrm{~F}$ & Head of Department & 4 years \\
\hline Steve & 2 & $20-30$ & $\mathrm{M}$ & Classroom teacher & 3 years \\
\hline Emma & 2 & $40-50$ & $\mathrm{~F}$ & Learning Resource Manager & 12 years \\
\hline
\end{tabular}


Table 3. Questions asked to students in Study 1 and Study 2

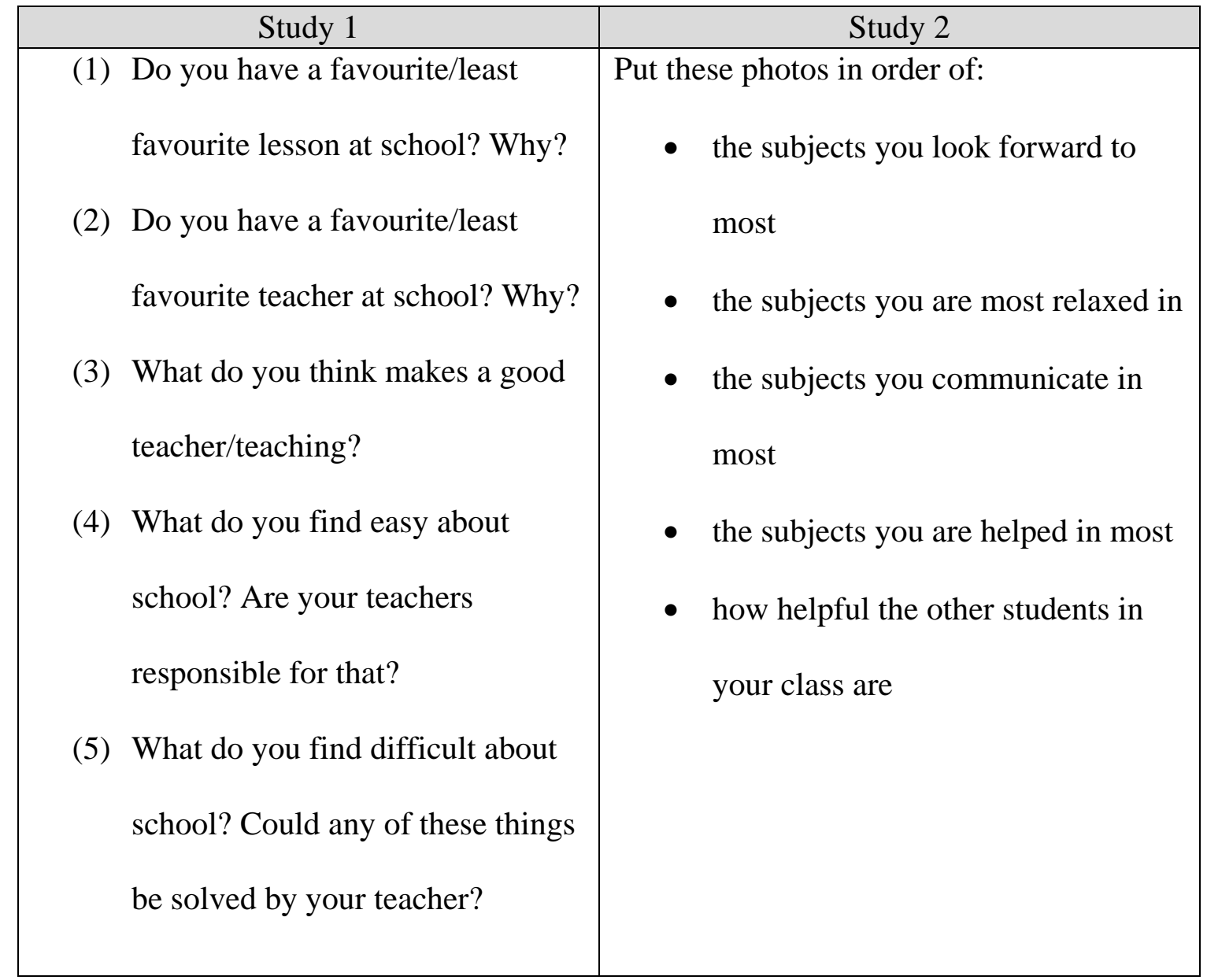


Table 4. Questions asked to school staff in Study 1 and Study 2

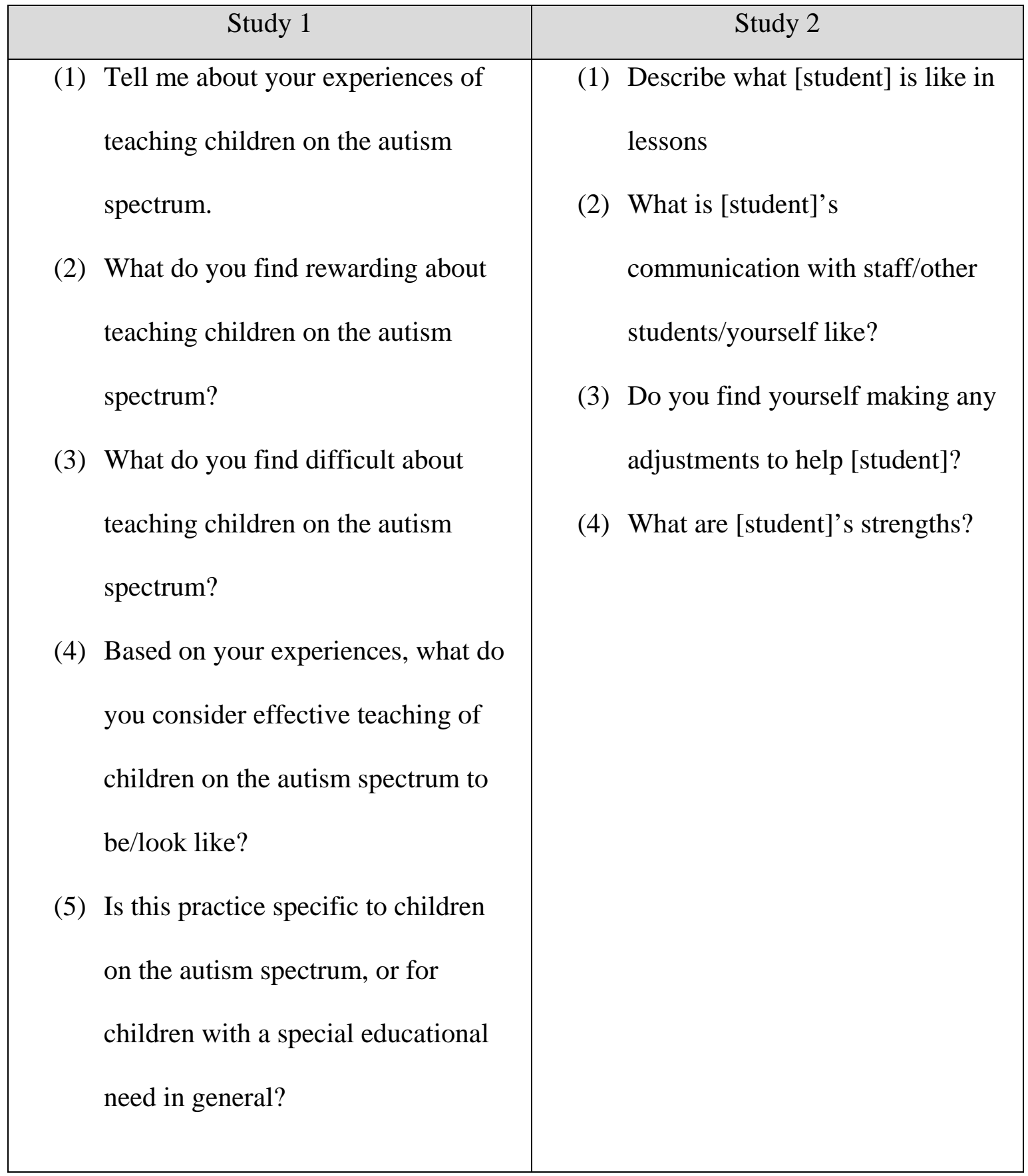


Table 5. Strategies for teaching students on the autism spectrum identified by staff from both studies and the number of staff who mentioned them.

Strategies identified

- Asking clear questions (9/10)

- Using verbal prompts (9/10)

- Using visual aids in the classroom (8/10)

- Verbally checking understanding (6/10)

- Using strategies in organising group work to engage students on the autism spectrum $(5 / 10)$

- Offering praise and encouragement (5/10)

- Treating the student like the rest of their classmates $(5 / 10)$

- Encouraging silent working (4/10)

- Sitting students on the autism spectrum with other students who may need clarification so that further explanation can be given easily to small groups $(4 / 10)$

- Redirecting irrelevant conversations (4/10)

- Using academically stronger peers to support students on the autism spectrum in class $(3 / 10)$

- Encouraging other students in the class to be more understanding/empathetic $(2 / 10)$ 
Table 6. Sensory differences and strategies identified by the students in both studies.

\begin{tabular}{|l|c|l|l|l|}
\hline Student & Study & \multicolumn{1}{|c|}{ Sensory difference identified } & \multicolumn{1}{|c|}{ Facilitating strategies } & \multicolumn{1}{|c|}{ Barriers } \\
\hline Benton & 1 & $\begin{array}{l}\text { High levels of auditory } \\
\text { stimulation and physical } \\
\text { movement }\end{array}$ & $\begin{array}{l}\text { Fidget tools; being allowed to stand up and } \\
\text { spin; learning through discussion }\end{array}$ & $\begin{array}{l}\text { Silent working; exam conditions; being } \\
\text { told off for fidgeting }\end{array}$ \\
\hline Daz & 1 & $\begin{array}{l}\text { High levels of somatosensory } \\
\text { stimulation }\end{array}$ & $\begin{array}{l}\text { Chewing gum to concentrate; biting pens; } \\
\text { being allowed to move in seat }\end{array}$ & $\begin{array}{l}\text { Having chewing gum confiscated and } \\
\text { then being told off for chewing on shirt } \\
\text { collar; being told to sit still }\end{array}$ \\
\hline Jeffrey & 1 & $\begin{array}{l}\text { High levels of personal space and } \\
\text { regulation of temperature }\end{array}$ & $\begin{array}{l}\text { Being allowed to sit near a window for } \\
\text { ventilation; being allowed to remove } \\
\text { blazer/jumper }\end{array}$ & $\begin{array}{l}\text { Seating plans where placement was next } \\
\text { to a student that 'spread out' their } \\
\text { belongings }\end{array}$ \\
\hline Lewis & 1 & $\begin{array}{l}\text { Low levels of auditory } \\
\text { stimulation; high levels of } \\
\text { personal space }\end{array}$ & $\begin{array}{l}\text { Individual working; quiet lessons; being } \\
\text { allowed to take 'time out' in the classroom }\end{array}$ & $\begin{array}{l}\text { Enforced group work; noisy, moving } \\
\text { classes (e.g. PE, DT) without a quiet } \\
\text { space }\end{array}$ \\
\hline Matthew & 1 & $\begin{array}{l}\text { Low levels of olfactory } \\
\text { stimulation (made nauseous by } \\
\text { certain smells) }\end{array}$ & $\begin{array}{l}\text { Being allowed to spend wet breaks in } \\
\text { classrooms rather than the canteen; being } \\
\text { allowed to sit near a window and open it to } \\
\text { breathe fresh air }\end{array}$ & $\begin{array}{l}\text { Being told off for sniffing certain } \\
\text { fabrics for comfort; being told off for } \\
\text { 'overreacting' to certain smells }\end{array}$ \\
\hline Stanley & 1 & $\begin{array}{l}\text { High levels of visual stimulation; } \\
\text { low levels of auditory stimulation }\end{array}$ & $\begin{array}{l}\text { Visual rather than verbal prompts; being } \\
\text { allowed to listen to music to concentrate }\end{array}$ & $\begin{array}{l}\text { Being told off for getting distracted by } \\
\text { new environments }\end{array}$ \\
\hline
\end{tabular}




\begin{tabular}{|l|c|l|l|l|}
\hline Yazi & 2 & $\begin{array}{l}\text { Low levels of auditory } \\
\text { stimulation; high levels of } \\
\text { physical movement }\end{array}$ & $\begin{array}{l}\text { Being allowed to fidget and doodle while } \\
\text { listening to instructions }\end{array}$ & $\begin{array}{l}\text { Being told off for reading a book rather } \\
\text { than talking to peers }\end{array}$ \\
\hline Sage & 2 & $\begin{array}{l}\text { Low levels of both auditory and } \\
\text { visual stimulation }\end{array}$ & $\begin{array}{l}1-2-1 \text { instruction and prompting; pair rather } \\
\text { than group work }\end{array}$ & $\begin{array}{l}\text { Being told off/punished for } \\
\text { 'withdrawing' when overloaded and } \\
\text { doing no work }\end{array}$ \\
\hline Genji & 2 & $\begin{array}{l}\text { High levels of both auditory and } \\
\text { visual stimulation }\end{array}$ & $\begin{array}{l}\text { 'Banter' and individual conversations with a } \\
\text { teacher; typing on an iPad rather than writing }\end{array}$ & $\begin{array}{l}\text { Silent working; lack of visual schedule } \\
\text { to refer to when distracted }\end{array}$ \\
\hline Hanzo & 2 & $\begin{array}{l}\text { High levels of both auditory } \\
\text { stimulation and physical } \\
\text { movement }\end{array}$ & $\begin{array}{l}\text { Energetic and noisy tasks; large group work; } \\
\text { being allowed to use fidget toy }\end{array}$ & $\begin{array}{l}\text { Silent working; being told off for } \\
\text { fidgeting; working with unfamiliar } \\
\text { students }\end{array}$ \\
\hline Bob & 2 & $\begin{array}{l}\text { Low levels of both auditory and } \\
\text { visual stimulation }\end{array}$ & $\begin{array}{l}\text { Whole class instruction; being 'leader' in a } \\
\text { group; pair work }\end{array}$ & Working with unfamiliar students \\
\hline Jack & 2 & $\begin{array}{l}\text { High levels of both auditory and } \\
\text { visual stimulation }\end{array}$ & $\begin{array}{l}\text { Colour-coding to keep subjects organised; } \\
\text { using interests for projects (e.g. creative } \\
\text { writing essay) }\end{array}$ & $\begin{array}{l}\text { Being told off for inappropriate affect; } \\
\text { instructions not given face to face (e.g. } \\
\text { shouted across the room) }\end{array}$ \\
\hline
\end{tabular}

\section{Word count}

